\title{
Development of novel fairness oil formulated from selected medicinal plants
}

\author{
*S.A.Y. Bimalsha and N.D. Kodithuwakku \\ Institute of Indigenous Medicine, University of Colombo, Sri Lanka \\ *Email:yethmibimalsha93@gmail.com
}

Received : 19.01.2020 ; Revised: 18.03.2021 ; Accepted : 25.03.2021

\begin{abstract}
There is a drug group in Ayurveda medicine which is indicated for discoloration of the skin. It is correlated with removing of pigmentations, skin dryness and improving the skin tone cosmetically. A study was aimed to prepare novel oil by using the method of oil preparation from selected drugs of the said group. Further, this study was focused to establish basic standardization procedures on new formulated oil to add scientific validity and analyzed the pharmacological actions of selected drugs. The oil was prepared in three methods in accordance with the authentic text to obtain the high yield and quality. Organoleptic parameters, phytochemical parameters and physicochemical parameters were applied to establish the standardization parameters.
\end{abstract}

The most predominant Ayurveda pharmacological actions of the drugs were Kapha-pitta Shâmaka action and increase of complexion of skin. Physico-chemical parameters of oils were as follows: $p H$ value of $A, B, C$ samples were: 5.46, 5.88, 6.55 respectively. Acid value of $A, B, C$ samples were: $5.049 \mathrm{mg}$ of $\mathrm{KOH}, 5.610 \mathrm{mg}$ of $\mathrm{KOH}$, $6.732 \mathrm{mg}$ of $\mathrm{KOH}$ respectively. Presence of alkaloids, tannins, saponins, flavonoids and terpenoids could be seen in all samples which were useful in the quality control and standardization of novel oil. Fairness effect could be proven conceptually via Ayurveda pharmacological actions of oil and scientifically via its wide range of phytochemical components as well as modern pharmacological findings such as tyrosinase inhibitors and Alpha and beta hydroxyl acids and derivatives. In conclusion, this novel oil would provide safe and effective action on skin complexion. However, to validate its therapeutic utility to scientific community, preclinical and clinical studies are essential.

Keywords: herbal drugs, complexion, standardization

\section{INTRODUCTION}

The fair skin concept has been made psychological and social impact on women which is considered to be affected on their personality. Recently men also concerned about fairness and handsomeness with the market promotions. As the demand on these cosmetics have elevated, it withholds the market at higher stand. Besides the busy lifestyle schedules, consumption of instant food, exposure to the polluted/unhealthy environment, and the bright sun, the discoloration of skin and the features of aging could be seen commonly among the people. Hence the high expenditure on skin care among the population has led to many more skin problem of pigmentations, loss of complexion and skin dryness (Kamakshi, 2012).

Prevailing whitening products in today market are containing of heavy metals, bleaching chemical agents, which are harmful. Hence recently, world trend turns to use medicinal plant products in health care system. Global need of herbal medicine has resulted in growth of natural product markets and improvement in traditional systems of medicine.

According to Ayurveda philosophy skin complexion is maintained by the Pitta Dosha. When Pitta Dosha is decreased and vitiated, the skin complexion is also diminished. Bhrâjaka Pitta is the accountable subtype of the Pitta Dosha for the maintenance of body complexion and it removes the pigmentation and discoloration of the skin (Prajnâsârabhidhâna, 1990). The moistness of the skin is wielded by the Susneha (oily) and Drava (liquidity) qualities of Pitta.

Novel "phytoactive" ingredients are revealing the development in cosmeceuticals and these ingredients include many beneficial properties in skin caring. Hence this study is based on the overcoming of current problems regarding skin complexion by inventing novel oil which was prepared with the use of selected medicinal plants. The selected medicinal plants were Raktha Chandana (Pterocarpus santalinus L.f.), Thunga 
(Calophyllum inophyllum), Padma (Nelumbo nucifera Gaertn.), Ushira (Vetiveria zizaniodes (L.) Roberty), Madhuka (Glycyrrhiza glabraL.), Manjishtâ (Rubia cordifolia L.), Sârivâ (Hemidesmus indicus (L.) R. Br.), Payasya (Pueraria tuberosa (Willd.) DC.). Further, establishing of the standardization parameters for the novel oil and then analyze its pharmacological action for the selected medicinal plants were the other aims of this study. Hence, the applicability of new formula is discussed by considering pharmacological properties of them in this study.
Further, this study possesses basic standardization procedures of new formulated oil.

\section{MATERIALS AND METHODS}

Selection, processing and quality evaluation of the raw materials

All the ingredients (Table 1 ) were collected cleaned and dried them well. It was then identified macroscopically and studied for important botanical characteristics. All ingredients were authenticated by Department of Dravyaguna Vignana, IIM.

Table 1:Collection of raw materials

\begin{tabular}{llll}
\hline & Used part & Sanskrit name & Botanical name \\
\hline For Kalka (paste) and & Pith & Raktha Chandana & Pterocarpus satalinus \\
Drava Dravya & Bark & Thunga & Calophyllum inophyllum \\
(liquid portion) & Stalk & Padma & Nelumbo nucifera \\
& Root & Ushira & Vetiveria zizaniodes \\
& Root & Madhuka & Glycyrrhiza glabra L. \\
& Root & Manjishtâ & Rubia cordifolia \\
& root & Sârivâ & Hemidesmus indicus \\
& Tubers & Payasya & Pueraria tuberosa \\
SnehaDravya(oil portion) & Oil & Nârikhela & Cocos nucifera \\
Kalka (paste) for Thaila & Outer cover of fruit & Nimbu & Citrus medica \\
Mûrchana(special & Leaf stem & Thâmbula & Piper betle \\
processing) & Seed & Krushnajîraka & Nigella sativa \\
\hline
\end{tabular}

Due to the unavailability of Padma kâshta, stalk of lotus (Nelumbo nucifera) was used as a substitute (Department of Ayurveda, 1994).

Preparation of Kalka (paste): Kalka Paribhâshâ of the Ayurveda drug preparation was followed to prepare the Kalka (Nagodavithana P, 2001).The coarse powder of dry ingredients was used to prepare the Kalka (Wijerathna, 2017).

Preparation of Kashaya (Decoction): Kashâya was prepared by adding 120 gof ingredients and $1920 \mathrm{ml}$ of water and simmered to 480ml (Nagodavithana, 2001).

Preparation of Thaila (oil): Paste: oil: liquid portion (Decoction) were mixed in the standard proportions to prepare the oil samples (Department of Ayurveda, 1994).

Sample A - The oil is heated up to MadyaPâka (Nagodavithana, 2001).

Sample B - The oil is heated up to KharaPâka (Nagodavithana, 2001).
Sample C - NârikhelaThailaMurchana (Nagodavithana, 2001) was done to the base oil. The oil is prepared by heating up to Khara Pâka.

Three repetitions were done to each 3 samples. Phytochemical analysis of the Kashâya (Decoction)

Test for Alkaloids: Crude extract was mixed with $2 \mathrm{ml}$ of $1 \% \mathrm{HCl}$ and heated gently. Mayer's reagent was added to the mixture. Appearance of cream colour precipitate indicates the presence of Alkaloid (Varughese and Tripathi, 2013).

Test for Tannins: Crude extract was mixed with $2 \mathrm{ml}$ of neutral $\mathrm{FeCl}_{3}$. A dark green colour indicates the presence of Tannins Alkaloid (Varughese and Tripathi, 2013).

Test for Saponins: Crude extract was mix with $5 \mathrm{ml}$ of distilled water in a test tube and shaken vigorously. The formation of stable foam taken as an indication for the presence of saponins Alkaloid (Varughese and Tripathi, 2013). 
Test for Terpeneoids: Crude extract was mixed with $2 \mathrm{ml}$ of chloroform and concentrated $\mathrm{H}_{2} \mathrm{SO}_{4}$ was added sideways. A reddish brown colour at the interface indicates the presence of terpenoids Alkaloid(Varughese and Tripathi, 2013).

All the tests were done 3 times for each sample.

Analytical study of the Thaila (oil)

Organoleptic characters: The oil samples were inspected for the differences of colour, odour, appearance, texture, and touch in the four samples.

$\mathbf{p}^{\mathrm{H}}$ Value: $\mathrm{p}^{\mathrm{H}}$ meter was used to determine the $\mathrm{P}^{\mathrm{H}}$ of four samples with threerepetitions for each.

Moisture content: Hot plate method was used to evaluate moisture content. Weighed quantity of oil was taken in a glass beaker, heated on the electric hot plate until the cessation of the rising bubbles of steam as well as the absence of foam. After cooling, it was reweighed. The difference in the weight, before and after heating was used to calculate the amount of moisture presents (loss on drying) (BIS, 2007). This was done 3 times for each sample and the values were declared as percentages.

Acid value: Weighed quantity of oil was taken and added $50 \mathrm{ml}$ of neutralized ethyl alcohol and $1 \mathrm{ml}$ of phenolphthalein indicator solution into it. The mixture was boiled for 5 minutes and titrated while as hot as possible with standard potassium hydroxide $(0.1 \mathrm{~N})$ solution, shaking vigorously while titration (BIS, 2007). Three Repetitions were done for each sample.

Acid value $=\frac{56.1 \mathrm{VN}}{\mathrm{W}}$

\section{RESULTS}

Phytochemical analysis of Kashâya (Decoction)
Where,

$$
\mathrm{V}=\text { Volume in } \mathrm{ml} \text { of standard } \mathrm{KOH} \text { solution }
$$
used,

$\mathrm{N}=$ Normality of standard $\mathrm{KOH}$ solution,

$\mathrm{W}=$ Weight in $\mathrm{g}$ of the oil taken .

Peroxide value: Weighed quantity of oil was dissolved in $30 \mathrm{ml}$ of glacial acetic acid: chloroform (3:2) solution. $0.5 \mathrm{ml}$ of saturated potassium iodide solution was added to it. After shaking it one minute, $30 \mathrm{ml}$ of distilled water was added. Then it was titrated with $0.1 \mathrm{~N}$ sodium thiosulphate solution with constant and vigorous shaking, using starch solution as the indicator, near the end point (BIS, 2007).The procedure was repeated for the 3 samples.

$$
\text { Peroxide value }=\frac{(\mathrm{S}-\mathrm{B}) * \mathrm{~N} * 1000}{\mathrm{~g}}
$$

Where,

$\mathrm{S}=$ Volume in $\mathrm{ml}$ of sodium thiosulphate solution used up by the sample,

$\mathrm{B}=$ Volume in $\mathrm{ml}$ of the sodium thiosulphate solution used up in the blank determination,

$\mathrm{N}=$ Normality of the sodium thiosulphate solution,

$\mathrm{g}=$ Weight in $\mathrm{g}$ of the sample

Analysis of the pharmacological actions of the ingredients: Analysis of pharmacological actions of the ingredients was done (Department of Ayurveda, 1994).

Table 2:Phytochemical analysis of Kashâya(Decoction)

\begin{tabular}{lccc}
\hline Phytochemical & Sample A & Sample B & Sample C \\
\hline Alkaloids & + & + & + \\
Tannins & + & + & + \\
Saponins & + & + & + \\
Terpenoids & + & + & + \\
\hline
\end{tabular}


Development of novel fairness oil from medicinal plants

Organoleptic properties of oil

Table 3: Organoleptic properties

\begin{tabular}{llll}
\hline Organoleptic properties & Sample A & Sample B & Sample C \\
\hline Colour & Reddish orange & Red & Red \\
Odour & Odour of coconut oil & Odour of coconut oil & Odour of coconut oil \\
Appearance & Transparent & Transparent & Transparent \\
Texture & Liquid consistency & Liquidconsistency & Liquidconsistency \\
Touch & Oily & Oily & Oily \\
\hline
\end{tabular}

Physico - chemical parameters

pH Value

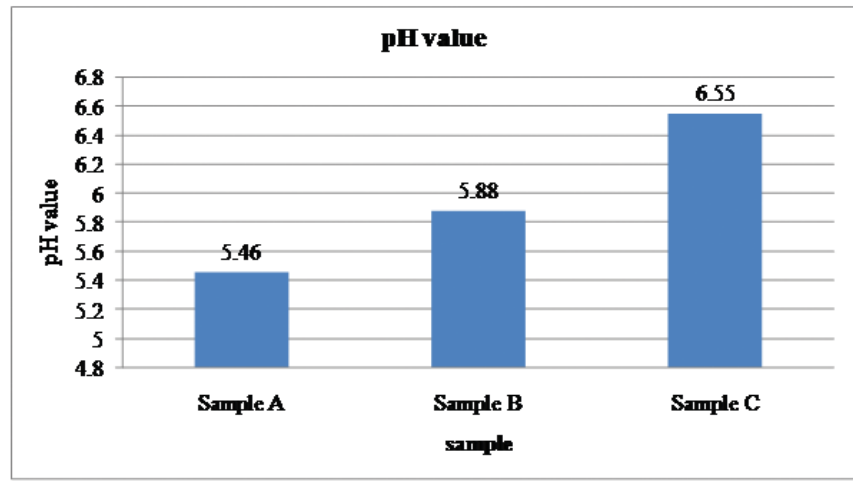

Figure 1: Varying of the $\mathrm{pH}$ value of samples.

Sample A- oil heated up to MadyaPâka,

Sample B- oil heated up to KharaPâka,

Sample C- oil prepared with Mûrchitha coconut oil and heated up to KharaPâka

The highest $\mathrm{pH}$ value is observed in sample C. The average $\mathrm{pH}$ value is 5.9.

\section{Moisture content}

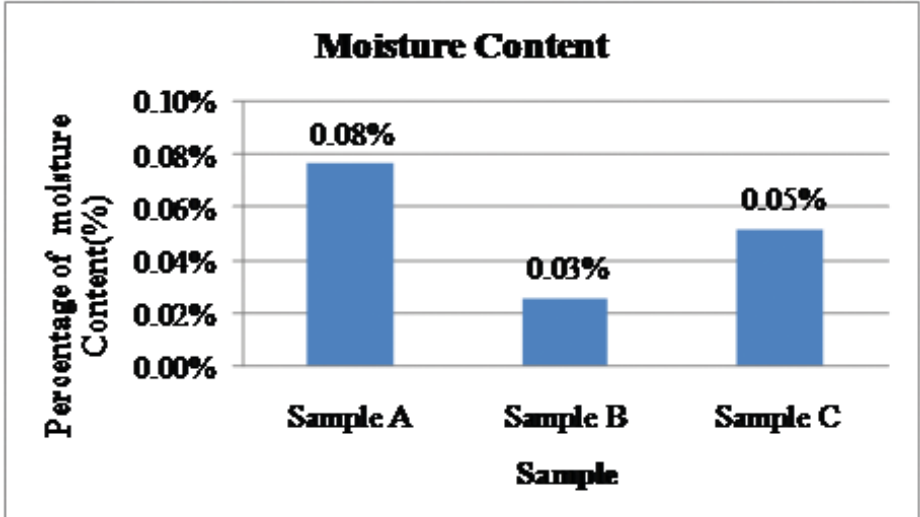

Fig. 2: Differentiation of moisture content of oil samples.

Sample A- oil heated up to MadyaPâka,

Sample B- oil heated up to KharaPâka,

Sample C- oil prepared with Mûrchitha coconut oil and heated up to KharaPâka

Highest percentage of moisture was presented in sample A and the lowest was in sample B. The average moisture content is $0.045 \%$. 
Acid value

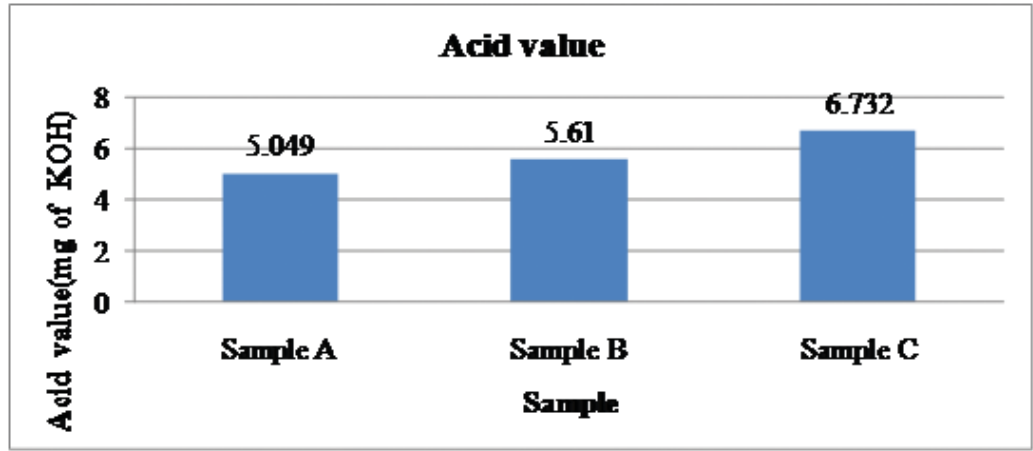

Fig. 3: Differentiation of Acid values of oil samples.

Sample A- oil heated up to MadyaPâka,

Sample B- oil heated up to KharaPâka, Sample

C- oil prepared with Mûrchitha coconut oil and heated up to KharaPâka

The highest acid value was presented in sample $C$ and lowest was in sample A. The average acid value is 5.797

\section{Peroxide value}

Peroxide value couldn't be determined because of the first colour change is difficult to observe due to the red colour of the oil.

Final volume of oil samples

Table 4:Final volumes

\begin{tabular}{lccc}
\hline Sample & Initial volume & Final volume & Percentage \\
\hline Sample A & $120 \mathrm{ml}$ & $100 \mathrm{ml}$ & $83.3 \%$ \\
Sample B & $120 \mathrm{ml}$ & $75 \mathrm{ml}$ & $62.5 \%$ \\
Sample C & $120 \mathrm{ml}$ & $70 \mathrm{ml}$ & $58.3 \%$ \\
\hline
\end{tabular}

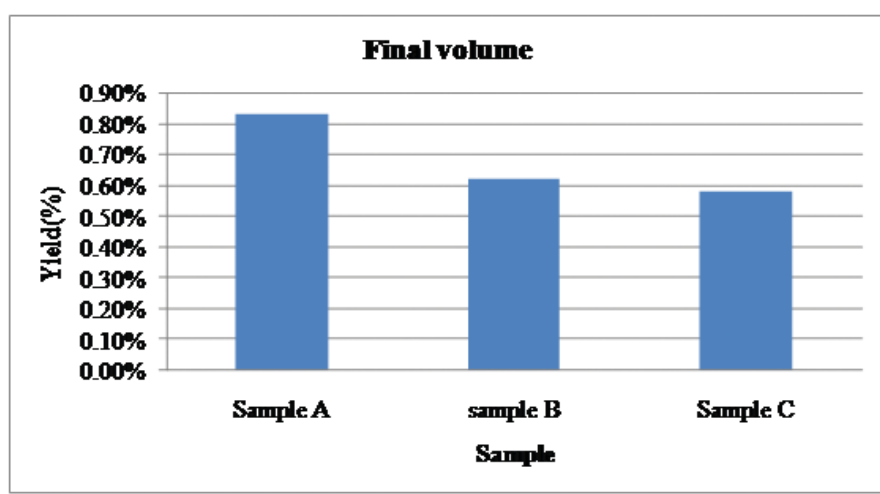

Fig. 4: Varying of the final volumes of oil samples

Sample A- oil heated up to MadyaPâka,

Sample B- oil heated up to KharaPâka,

Sample C- oil prepared with Mûrchitha coconut oil and heated up to KharaPâka.

Highest yield was obtained from sample A and lowest was obtained from sample C.

Pharmacological actions according to Effecton Dosha and External therapeutic action 
Table 5: Pharmacological properties according to effects on Dosha and external therapeutic action

\begin{tabular}{|c|c|c|}
\hline Ingredients & Effect on Dosha & External therapeutic action \\
\hline $\begin{array}{l}\text { Raktha Chandana } \\
\text { (Pterocarpus satalinus) }\end{array}$ & Pacify Kapha, Pitta & $\begin{array}{l}\text { Pacify burning sensation, relieve disorders of } \\
\text { skin, relieve swellings }\end{array}$ \\
\hline Thunga(Calophyllum inophyllum) & Pacify Kapha, Pitta & Scraping action, analgesic action \\
\hline Padma(Nelumbo nucifera) & Pacify Kapha, Pitta & Increase complexion, pacify burning sensation \\
\hline Ushira(Vetiveria zizaniodes) & Pacify Kapha, Pitta & Pacify burning sensation, relieve disorders of skin \\
\hline Madhuka(Glycyrrhiza glabra L.) & Pacify Vâta, Pitta & $\begin{array}{l}\text { Pacify burning sensation, relieve swellings, } \\
\text { beneficial on hair }\end{array}$ \\
\hline Manjishtâ(Rubia cordifolia) & Pacify Thridosha & Pacify burning sensation \\
\hline Sârivâ(Hemidesmus indicus) & Pacify Thridosha & Pacify burning sensation, relieve swellings \\
\hline Payasya(Pueraria tuberosa) & Pacify Vâta, Pitta & Increase complexion \\
\hline Sithâ (controversial) & Pacify Vâta, Pitta & - \\
\hline Durvâ(Cynodon dactylon) & Pacify Thridosha & Pacify burning sensation \\
\hline
\end{tabular}

Pitta - Kapha Shâmaka effect, increasing complexion and Pacify burning sensation actions prominent in Varnya Dashaka.

\section{DISCUSSION}

In this research to prepare the novel oil, the drug group which is called Varnya Dashakaya is used as the base formula which is mentioned in Ayurveda authentic text, Charaka Samhithâ. Based on the availability and non-controversial, herbs were selected for the novel oil and techniques were followed for the manufacturing and quality evaluation of oil. Hence 08 drugs of the oilwere used for the preparation except Sithâ and Durvâ due to its controversiality. Some authentic text have mentioned Sithâ as Shvetha Durvâ (Kumârasinghe, 1991) and some as sugar cane(Sharkarâ) (Department of Ayurveda,1994). Durvâ has mentioned as Krushna Durvâ/ Nil Îthana (Kumârasinghe,1991) and it was difficult to find. Also Lotus stalks (Nelumbo nucifera) were used as a substitute for Padmakâshta (Department of Ayurveda,1994). The commonly used part of each drug was used for the preparation.

Decoction of the 08 drugs was used as Drava Dravya (Liquid portion) for the preparation of oil. The modified proportion of methodology of preparation of decoction was used which is mentioned in an Ayurveda text book, Shârangdhara Samhithâ in order to get the high yield of oil.

Coconut oil was used as the base oil as it is rich in nutrients such as vitamin E, as well as with good essential oils. Conversely, based on its nutritional and pharmacological effects coconut oil has been identified as best for all the types of skin and its common in availability. It has anti-fungal, antibacterial and anti-viral properties that make it beneficial for the immune support (Patil, 2018). Thus coconut oil itself possesses advantageous in skin complexion and anti-aging effects and adding of the drugs of Varnya Dashakaya would enhance its effectiveness. At the same time Varnya Dashakaya provided an attractive colour and fragrant to the oil.

Mûrchana is a special process that is commonly used in Ayurveda oil preparation to enrich its efficacy, quality and shelf life. Therefore to assess the validity of Mûrchitha Thaila in this kind of preparation Sample C was prepared by using Mûrchitha Coconut oil (Department of Ayurveda,1994).

Phytochemical studies were done only for the Kashâya (Decoction) because the same drugs were used to Kalka (Paste) and Kashâya (Decoction).The oil was consisted with phytochemicals such as Alkaloids, Tannin, Terpenoids, Saponin. Hence, the oil has anti-bacterial, anti-fungal and anti-oxidant properties which will be beneficial in skin complexion as well as in providing protection from pathogenic bacteria and fungi.

The reddish colour of oil is due to the Manjishtâ (Rubia cordifolia) and Raktha Chandana (Pterocarpus satalinus)which are ingredients of Kalka(Paste) and Kashâya (Decoction). Characteristic odour is due to the coconut oil which used as base oil and pleasant aroma was presented due to herbs.

The average $\mathrm{pH}$ is 5.9 and this average $\mathrm{pH}$ is beneficial and safe for skin (Lambers, 2006) as the normal skin $\mathrm{pH}$ is about $4.5-5.5$. 
The average moisture content of oil is $0.045 \%$. Highest percentage observed in sample A $(0.077 \%)$ as it was prepared up to Madya Pâka. Hence this average percentage is beneficial for the persistence of shelf life of the oil.

Standard acid value of coconut oil is about $6.00 \mathrm{~g} / \mathrm{mg}$ of $\mathrm{KOH}$ (Auriga Research, 2013). Although the sample $\mathrm{C}$ is bit higher than reference range still all the samples are in the required range. An acid value is associated with the shelf life of the oils and it is the measure of free fatty acids of oil. It is an indicator of inadequate processing and storage conditions (i.e., high temperature and relative humidity).

Good average of yield (68\%) can be seen in final volume in all samples due to use of the coarse powder for Kalka Dravya (paste).

In Ayurveda, process of formation of skin in foetus is attributed to Pâka of Raktha Dhâthu. Agni Mahâ Bhûta (heat) is said to be at the root of formation of complexion (Trikamji, 2005). There are 7 layers of skin according to the Ayurveda and the first layer which is called as Avabhâsinî is the responsible layer for the complexion of the body. Brâjaka Agni/ BrâjakaPitta have located in the first layer (Prajnâsârabhidhâna, 1990). This helps to make the lustre and complexion of body.

When Pitta Dosha gets vitiated, the action of Brâjaka Pitta is diminished. Then luster and complexion is decreased and discolorations are occurred. The Âma of skin is increased and Kapha Doshagets vitiated. Hence unctuousness of skin and skin tone get diminished.

According to the modern science skinlightening ingredients can also be classified by their source, such as classes to which they belong. The important classes are;

i. Chemical tyrosinase inhibitors (hydroquinone and similar type of compounds)

ii. Botanicals (essentially from plants and algae)

iii. Anti-oxidants

iv. Vitamins - A, B, C, E

v. Peptides

vi. Alpha and beta hydroxyl acids and derivatives

Among them botanical extracts mostly contains a combination of two or more classes of compounds that works synergistically to achieve skin lightening. Botanicals connote nature and are hence more acceptable to people (Kmakshi, 2012).
According to Ayurveda, the herbs which alleviate Pitta, Raktha and also Kapha in general either acting through their Rasa, Vipâka or Prabhâva considered as Varnya. This oil has Madhura, Tiktha, Kashâya Rasa, Guru, Snigdha Guna, Shîtha Vîrya and Madhura Vipâka which is pacify the Pitta Dosha and has Tiktha and Kashâya Rasa which are pacify Kapha Dosha and retain the action of Varnya.

Hence this oil is capable in improving skin complexion, luster, moistness and skin tone.

This Oil is developed for the first time as a novel product for the given drug list and would be beneficial in skin complexion which will be popular among the beauty conscious people. The pharmacodynamics properties proved its capability as a cosmetic product. However further studies are essential to develop this as a marketed product.

\section{REFERENCES :}

Auriga Research Pvt.ltd. 2013.Oils [http:// foodsafteyhelpline.com/2013/03/oils/] Accessed 21 July 2018.

Ayurveda Aushadha Samgraha. 1994. Sinhala Edition: Vol 1;Part 2; Department of Ayurveda, Colombo, Sri Lanka, p110.

Ayurveda Aushadha Samgraha. 1994. Sinhala Edition: Vol 1; Part 1;Department of Ayurveda, Colombo, Sri Lanka, p35.

Ayurveda Aushadha Samgraha. 1994. Sinhala Edition: Vol 1; Part 2;Department of Ayurveda, Colombo, Sri Lanka, p36.

Ayurveda Aushadha Samgraha. 1994. Sinhala Edition: Vol 1; Part 3;Department of Ayurveda, Colombo, Sri Lanka, pp60- 321.

Ayurveda Aushadha Samgraha. 1994. Sinhala Edition: Vol 1;Part 1;Department of Ayurveda, Colombo, Sri Lanka, p14.

BIS, 2007. Sampling, Physical and Chemical tests, Indian standard methods of sampling and test for oils and fats: Part 1, Bureau of Indian Standards, New Delhi, India, p20

BIS, 2007. Sampling Physical and Chemical tests; Indian standard methods of sampling and test for oils and fats: Part 1, Bureau of Indian Standards, New Delhi, India, p29

BIS, 2007. Sampling, Physical and Chemical tests, Indian standard methods of sampling and test 
for oils and fats: Part 1, Bureau of Indian Standards, New Delhi, India, p.64

Kmakshi, R. 2012. Fairness via Formulation: A Review of Cosmetic Skin- lightening Ingredients: Journal of Cosmetic Science, 63(1): 46.

Kumârasinghe A.1991. Caraka Samhitâ, Sûtra Sthâna: Sinhala Edition: Vol 1; Department of Ayurveda, p29.

Lambers, H., Piessens, S., Bloem, A., Pronk, H. and P. Finkel. 2006. Natural Skin Surface ${ }_{\mathrm{p}} \mathrm{H}$ is on avarage below 5 , which is beneficial for its resident flora, Pub Med, International Journal of Cosmetic Science, 28(5): 359-370

Nâgodavithâna, P. 2001. Sharângdhara Samhitâ, Madhyama Khanda: Sinhala Edition: Samayawardhana Publications, Colombo, Sri Lanka, p171.

Nâgodavithâna, P. 2001, Sharângdhara Samhitâ, Madhyama Khanda: Sinhala Edition: Samayawardhana Publications, Colombo, Sri Lanka, p172

Nâgodavithâna, P. 2001. Sharângdhara Samhitâ, Madhyama Khanda: Sinhala Edition: Samayawardhana Publications, Colombo, Sri Lanka, p123
Patil K. 2018. Properties of Coconut oil: Organic Information services, India.

Prajnâsârabhidhâna K.S. 1990. Susruta Samhitâ, Sharîrasthâna: Sinhala Edition: Vol 3; Department of Ayurveda, Colombo, Sri Lanka, p149

Prajnâsârabhidhâna K.S. 1990. Susruta Samhitâ, Sharîrasthâna: Sinhala Edition: Vol 3; Department of Ayurveda, Colombo, Sri Lanka, p151

Trikamji AY, 2005. Susruta Samhitâ: Varanasi Chaukhamba Oriantalia, Varanasi, India, p348

Varughese, B and Tripathi J. 2013. Phytochemical Evaluation of different solvent extracts of Aelgle marmelos fruit at different stages of its ripening. Advances in Life Science and Technology, 8: 8-12.

Wijerathna K.M.C.H. 2017. Establish the standards of Roma Nashaka Karaviradi Tailaya (Not published). Chapter 2. Institute of Indeginouse Medicine, University of Colombo, Sri Lanka. p21 